\title{
Head and Neck Cancer Pathologic TNM
} Finding v8

National Cancer Institute

\section{Source}

National Cancer Institute. Head and Neck Cancer Pathologic TNM Finding v8. NCI

Thesaurus. Code C132642.

A pathologic finding about one or more characteristics of head and neck cancer, following the rules of the TNM AJCC v8 classification system. 